International Journal of Social Science and Economic Research

ISSN: 2455-8834

Volume:06, Issue:07 "July 2021"

\title{
A NEW COLD WAR OR STRATEGIC COMPETITION?
}

\author{
Sankalp Rawal \\ Department of Economics, Aryabhatta College, University of Delhi, New Delhi, India, 110021 \\ DOI: 10.46609/IJSSER.2021.v06i07.025 URL: https://doi.org/10.46609/IJSSER.2021.v06i07.025
}

\begin{abstract}
China's success in closing the national power gap between itself and the United States has contrived a new threat for the United States global primacy. Lately, quite a few research elites and scholars have scrutinized the ever-intensifying competition between the United States and China and its multidimensional ramifications for the world economy. Unlike Cold War 1, factors such as economic and technological supremacy hold great importance for both rivals apart from international prestige and leadership. The gravity of the situation is easy to assume as many policymakers are bothered about the prospect of a new Cold War between the two countries. The agony is justified since both countries jointly constitute more than one-third of the world's GDP. It implies contention between the two states could have large scale adverse implications on the growth of the world economy, especially emerging economies and already-stressed global supply chains. However, cooperation among them can foster economic growth, preserve the integrity of an open and robust trading system and pave the road to global prosperity. This paper seeks to offer an analysis of the circumstances which led to the rise of China as a global economic leader, which in turn caused strategic competition between the United States and China. In addition, several recommendations to resolve the ideological differences between the two nations will also be examined.
\end{abstract}

Keywords: Cold War, Cooperation, Leadership, Rival, Strategic Competition

\section{Introduction}

\subsection{What is Cold war?}

According to Dr. Andrew Hartman, Head Professor of History at Illinois State University, "Cold war is a state of tension between countries in which each side adopts policies designed to strengthen itself and weaken the other by falling short of actual war." Unlike a usual war, a Cold War is fought without weapons. The first-ever Cold War fought between the United States of America and the Soviet Union lasted for 44 years (1947-1991). The US managed to win that war exclusively based on military and cultural aspects. Since then, no country has been able to pose a 


\section{International Journal of Social Science and Economic Research}

ISSN: $2455-8834$

Volume:06, Issue:07 "July 2021"

challenge to the US due to its strong military forces and remarkable economy with a GDP of USD 22.32 trillion (FY20). However, the boom of the Chinese economy, in recent years, has raised many questions similar to those being asked at the beginning of Cold War 1.

\subsection{China's emergence as a superpower}

China, identified as a revisionist power with the Russian Federation, in the 2017 National Security Strategy (National Security Strategy, 2017: 25) report of the Trump government has become a superpower in the 21 st century with its spot in the world economy. A superpower state ensures international security, intervenes in every region either as an ally or as an intervener with the military power held, supported by the economic capacity (Buzan and Waever, 2003: 394). Not only the competition with the US, the work China has carried out as a revisionist power, endeavours to regulate the new economic order, assuming military, political and financial administration in the Asian region where it is located, and transforming into a military power that is viable with the present advances in terms of military strength on account of its economic strengthening and situating it particularly as a marine and space power, its exhaustive effort to turn into a pioneer in artificial intelligence can contend as the causes behind this insight.China began strategic exercises with the US Nixon government in 1972 and implemented the opening up and transforming the economy with Deng Xiaoping after the founding pioneer Mao Zedung. China, having understanding at the beginning phases long before the breakdown of the Soviet Union's economy in 1991 that such a philosophical financial model would not carry the country to the ideal welfare level, has become a Marxist country that approaches to deal with the West while the world was being shared by two unique blocks. It expressed that the US political circles offered all the essential help required for debilitating the Eastern alliance of that period and transforming China into a country like the US.

\subsection{Unprecedented Cold war}

Although the new Cold War showcases characteristics similar to those of the first Cold War, like contention between strong forces and ideological dissimilarities, there are many points of distinction between the two. In the first place, the United States and the Soviet Union were part of two contrasting international frameworks during the Cold War, and there were no economic connections between them, while under the ostensible new Cold War, the major forces essentially belong to one international framework, with mutually subordinate financial ties. Secondly, the quarrel between the rivals during the Cold War was showcased through contests between military powers. On the other hand, the new Cold War is manifested by a geo-economic rivalry between the US and China. Thirdly, the Cold War was outlined as a battle between the philosophies of capitalism and communism whereas, the new Cold War is a battle between different advanced models wherein online media and other advancements permit the great 


\section{International Journal of Social Science and Economic Research}

ISSN: $2455-8834$

Volume:06, Issue:07 "July 2021"

powers to exert political impact over their rivals. Fourthly, there were clear divisions between the two rival camps during the Cold War, while in the new Cold War, adversaries can even be companions, and financial accomplices can be security rivals. Also, the new Cold War is marked by rivalries among the US and China for control of global commons, like the Internet and space, wherein challenges are associated with holding control over connectivity instead of expansion of territory.

Hence, in this paper, I intend to examine China's relation with the US through a new Cold War perspective. Although there are several differences between these two states, this paper draws more attention to the recent happenings. First, the rise of China as a superpower, then a possible cold war between the two states and recommendations to de-escalate the situation form the essence of this study.

\section{Materials \& Methods}

A Cold War driven by the display of power, diplomacy, propaganda and economic aid can increase tension between the states and hamper trade relations and global peace, so performing an analytical study on their plausible causes becomes imperative. Many scholars and researchers, in recent time, have tried to explain the circumstances which could lead to a Second Cold War between US and China. Some have also compared the current scenario with that prevalent during the emergence of Cold War 1 to draw a better understanding of the situation.

\subsection{Insights from research papers and report}

One such example is the paper written by Minghao Zhao from the Institute of International Studies, Fudan University. His research paper offers an analysis of Chinese perspectives in USChina conflicts. According to his article, few Chinese professionals believe that US-China strategic competition is unavoidable as China is closing the national power gap with the United States. In his view, certain Chinese scholars pay more importance to US-China competition over international prestige and leadership. However, Chinese analysts are not overly pessimistic about the prospects for US-China relations and suggest policy recommendations geared to managing US-China strategic competition and restoring a new equilibrium between the two major powers. Another example is the paper written by AskininciSokmen of T.C. ArelÜniversitesi. It provides deep insight on topics such as why China is perceived as a threat, whether it can become a global leader and the consequence for the international system if a cold war emerges. She feels that China has great potential to become a future global leader. Moreover, she believes that a Cold War between the US and China is hypothetical as a single state cannot solve all global problems. Furthermore, a report written by Dr. Alan Dupont, a senior researcher at Hinrich Foundation provides a comprehensive analysis of a New Cold War between China and the US. It analyses 
International Journal of Social Science and Economic Research

ISSN: 2455-8834

Volume:06, Issue:07 "July 2021"

the causes of the conflict between the two states and provides several suggestions for assuaging the worst-case scenarios. According to Dupont, the Second Cold War can prove more dangerous than the first, given the interdependence of the US and Chinese economies and the expansion of their military forces and digital technologies.

\subsection{Insights from book by David S.Painter}

On the other hand, David S.Painter, the Director of Graduate Studies in History in the School of Foreign Service at Georgetown University, provides a compact and analytical study in his book that examines the origins, the course, and the end of Cold War 1.He claims that a Cold War mainly involves political and economic competition among the core capitalist states and ideological conflict within and among states. He believes that the global distribution of power intersected with military technologies and strategies, ideological crosscurrents, the ongoing restructuring of economies and societies, and political, economic, and social change in the Third World to produce, prolong, and, eventually, end the Cold War 1. His book focuses on structures and processes rather than individuals. Although his article focuses on Cold War 1, various instances are analogous to the current layout. Hence, his book assists in drawing similarity between Cold War 1 and the current timeframe.

\section{Rise of China as a Global Leader}

\subsection{Roots of communism and Chinese vision of development}

China's quality of being a revisionist power comes from the fact that it has fabricated its political designs since its foundation in 1949. The Chinese understanding of communism arose with the transformation made based on the logical perspective, the hypothesis of proletarian revolution, the hypothesis of communism and the development of socialism of Marxism spearheaded by Karl Marx and Friedrich Engels, putting the proletariat into the centre. Nationalist communism, in light of the working class, had become the fundamental political structure. Mao had designated the state he established as a democratic people dictatorship on the initiative of the common labourers and the partnership between the specialists and workers. Mao Zedong, who negated with USSR Leader Stalin due to his refusal to acknowledge his authority, accomplished communist modernization by gradually saving the country from underdevelopment. The pioneer Mao believed that the individuals base, who had confidence in the system, a strong party and an invincible and advanced armed force from the military point of view were the primary assets important for the endurance of the state (Junjian, Hua furthermore, Mian, 2018: 45-50). To date, the Chinese govern their system by following these standards. Deng Xiaoping is the central architect of China's communist reform, global expansion and development of modernization. In his hypothesis called with his name, he proposed techniques on the most proficient method to 


\section{International Journal of Social Science and Economic Research}

ISSN: $2455-8834$

Volume:06, Issue:07 "July 2021"

establish socialism in a financially and socially primitive nation like China. Deng's changes have been unique with respect to the Soviet Union framework from the very beginning. He intended to open China to the world by accomplishing four modernizations in agriculture, industry, military, and science/innovation. With these advancements, he figured out how to make the country, with a massive populace, the second-biggest economy in the world (Vogel, 2011: 94). China intends to transform into a powerful, majority rule, rich, contemporary, harmonious communist country in 2049, the 100th commemoration of the People's Republic of China. Within the scope of the three-stage technique, it intends to expand the gross domestic product persistently and raise the lifestyle of its people to the degree of the middle-level developed nations (Bougon, 2017: 22).As far as Xi Jinping's administration is concerned, he pursues to administer the nation by executing the Chinese implementation of Marxism based on the leader Mao's interpretations. When the Chinese president started his term, he took over numerous internal and external problems like increased unemployment, income inequality, dissatisfaction among the working-class, corruption, Xinjiang and Tibet issues, increasing tension with Japan, etc. Through policy reforms, he reinforced his policy-making powers and constructed a more centralized policy in the Chinese governance framework. Hevowed to rebuild the current civilization into one known as the "Middle Kingdom" which was a global leader in social, scientific, technological and administrative aspects beginning from the 16th century. The "Central Country" or "Middle Kingdom" idea involves past reasoning that regards Chinese culture and lifestyle as better than the West and states them as "barbarians" (Chexnaux, Bastid and Bergere, 1977:9).

\subsection{Global status of China}

China has become a global leader thanks to its position as the production house for the world economy, the world's most populated nation, the rapidly modernized military framework, new advancements, and remarkable achievements in the field of space. Assuming the leadership of globalization in the world economy, it is the head of the alternative block called emerging economies (E-7) (India, Brazil, Russia, Indonesia, Mexico, and Turkey) and is a member of BRICS. China has a huge foreign trade surplus in terms of economic data, and it attempts to increase its income per capita every year. However, being the world's most populated nation, the export-based economy can generate only low per capita income. Although China strives for alternative currencies other than the US Dollar in international trade, it has successfully implemented many projects in Eurasia, Middle East and Africa in the discipline of energy. It also plans to unveil a digital currency that could challenge dollar dominance. It has been running several trials on "Digital Currency Electronic Payment" (DC/EP) system - a digital yuan controlled by the central bank. If such a currency gains large-scale popularity, then it would help China to free itself from the US global financial order. China also plans to revive the historical Silk Road within its "One Belt One Road" venture and create a new economic region called 
International Journal of Social Science and Economic Research

ISSN: 2455-8834

Volume:06, Issue:07 "July 2021"

"Afro Eurasia".This domain was called the "Old World" before the revelation of the United States and comprised of Eurasia (i.e. merger of Europe and Asia) and the African mainland. With the completion of the Silk Road Generation Project, China would become the political focal point of the world. To explain the notion of geopolitics, several hypotheses have sighted the direction given to politics by geography (Cohen, 2009: 11). Mackinder suggested the idea of Heartland (Heart of the World) in his "Geographical Pivot of History" and expressed the region where Africa, Asia and Europe converged as the "World Islands". He affirmed that those who control the geological domain where these three landmasses meet would rule the world (Mackinder, 1904).Chinaalso aims to gather support from other countries by aiding developing countries in developing infrastructure investments within the framework of the mutual win-win principle. In this way, it has built 18 military naval bases around the world (Chongjin port North Korea, Moresby port - Papua New Guinea, Sihanoukville port - Cambodia, Koh Lanta port - Thailand, Sittwe port -Myanmar, Dhaka port- Bangladesh, Gwadar port- Pakistan, Hambantota port- Sri Lanka, Maldives, Seychelles, Djibouti port- Somalia, Lagos port -Nigeria, Mombasa port-Kenya, Dar-es-Salaam port- Tanzania, Luanda port - Angola and Walvis Bay harbour Nambia) (Chansoria, 2019).

\section{US-China Relations: A New Cold War?}

Although China and the US view each other as powerful opposition states in military and economic strength, they have many other differences in opinion and ideology. Lately, the disparities between them have exacerbated, leading to increased friction between the two states in diplomatic and political terms. Hence, this section evaluates a set of prime events which have prompted many scholars and researchers to assume the beginning of a new cold war between the US and China.

\subsection{Quarrel over origin of covid-19}

Many American professionals view Covid19 coordination with China as a "self-harming exercise in zero-sum competition for global leadership", but the Chinese perceive it as an opportunity to improve the economic and geopolitical influence of the US as foreigners look to invest in early recovered economies. The US has criticized China many times for hiding the facts regarding the virus, which ultimately led to a pandemic. Trump unapologetically named Covid19 "the Chinese virus" and blamed China for permitting it to get out of hand. The US also stopped its funding to WHO for failure in performing its duty. Not only this, but the US also ruled out Phase 2 of the trade deal due to China's incompetency in handling the coronavirus outbreak. In justification, China argued that such a virus could emerge from anywhere and anytime. "There is zero legal basis for holding China accountable and making it pay for COVID-19... COVID-19 is a natural, not human-made, disaster," the Chinese statement said. Till now, several litigations 
International Journal of Social Science and Economic Research

ISSN: 2455-8834

Volume:06, Issue:07 "July 2021"

have been filed against China in US courts prompting Beijing to ponder sanctions against US entities and individuals as a response. In its defence, the Chinese Government asserted that China "did not fear" an independent international investigation team visiting China. Moreover, the Chinese experts criticize the US for supporting the research in Wuhan's lab involving an analysis of bat specimens obtained from caves in China to study their potential for infecting humans.

\subsection{Beginning of Trade war}

In addition, the world also witnessed a Trade War between US and China, both attempting to increase their tariff rates on imports leading to an extensive high price of the commodities in the international market. To end this war, both parties came to the negotiating table to find a solution. At last, they decided that China will buy products and services of at least $\$ 200$ billion for the next two years, create strict laws to protect foreign IP, patents and trademarks. On the other hand, the US will have to reduce its tariff charges and refrain from competitive currency devaluation. China claims that it bought all the 50 items it committed to in the first four months of its trade deal with US. Besides, China continues to buy American commodities, such as agricultural products. Another Chinese statement claimed that although the Trump administration has taken aggressive tactics on TikTok, "Beijing is providing greater convenience for American companies, especially financial companies, to enter the Chinese market."In the end, although Phase 1 of the trade deal seems to have resolved the quarrel, the solution is temporary as it is unlikely for both states to fulfil all their promises. Besides, the genuine risk of the stage one deal is that it takes the world further down the way towards a power-based trading framework where the powerful do what they need, and the powerless endure what they should.

\subsection{Rise of technological competition}

Technological competition is vital for advancement and a powerful, running liberal trading framework. The Trump administration holds China guilty for dodging and controlling competition rules to gain and steal IP that is the backbone of the US economy and deliberately focusing on advanced US and Western technologies to lead the technology sector in the future. The US has blamed the Chinese intelligence services for stealing its military secrets. In February 2020, US Attorney-General William Barr arraigned four Chinese military officials for complicity in purloining the personal data of around 145 million Americans in a massive hack of giant US credit agency Equifax. Barr claimed China as the sole country to sweep data of the general public for meeting the prodigious data prerequisites of their world-leading AI sector. Another controversy over technology also took place recently. The US has been trying to manipulate its allies decisions over the usage of Huawei5G. The US asserted that using Huawie5G threatens the national security of a nation and infiltrates telecommunication infrastructure. As a result, Huawei5G got banned in the UK, New Zealand and Australia, the old allies of US. However, 
International Journal of Social Science and Economic Research

ISSN: 2455-8834

Volume:06, Issue:07 "July 2021"

China argued that no country had an issue with Huawei until Washington pressurized its allies to forgo the best services offered by the company. In its defence, the Chinese Foreign Ministry Spokesperson said "as far as banning of Hauwei5G by US and its allies is concerned, out of strong ideological prejudice, the US smears and attacks a Chinese company by using its national resources, in the name of "national security'."

\subsection{Dispute in South China Sea}

The dispute over Chinese ownership of the islands in the South China Sea is also a big concern. China claims these islands to be their property as their trading activities in the region date back to 2000 years ago. The Chinese Government has always remained stationary in maintaining its territorial sovereignty and maritime rights and interests in the South China Sea. China also firmly opposes the invasion and illegal occupation by certain states of some islands and reefs of China's NanshaQundao, and activities transgressing upon China's rights and interests in relevant maritime areas under China's jurisdiction. On the other hand, the US opposes that under UN Convention of the Law of the Sea (UNCLOS), it should have the freedom of navigating through the Economic Exclusive Zone (EEZs) and need not intimidate the claimant of military activities. The United States motive to resist China's treatment of the South China Sea as its 'maritime empire' shows the world is coming to terms with its military assertiveness and expansionist worldview.

\subsection{US intervention in Hong Kong and Taiwan}

Another major dispute lies with the Special Administrative Region (SAR) of China, i.e., Hong Kong. Under this act, Hong Kong being part of China has its own set of rules and policies that provides a smooth path for financial transactions and trade with the US. The anti-Beijing rally, which took place in Hong Kong, made China desperate to formulate a new plan to suppress terrorism. Henceforth, changes in international trade and policies are apparent. US protested against this action as it would affect the free flow of trade between Hong Kong and US and put more restrictions on transactions similar to China's case. Removal of the special status would lead to greater scrutiny of investment in US by Hong Kong companies just like it has been for Chinese companies in the past few years. Likewise, the Taiwan issue is perturbing. The Chinese see Taiwan as part of their territory and not as an independent state. The year 2020 has witnessed a marked increase in the scope of air and naval military exercises in and around the Taiwan Strait.A big reason for this increasing tension is the US intervention. The US passed several bills such as the Taiwan Travel Act and Taiwan Defense Act to help Taiwan in acquiring weapons from the US to defend itself against the Chinese. The US has also increased its military presence in the region to degrade and defeat any Chinese attack against Taiwan. 
International Journal of Social Science and Economic Research

ISSN: 2455-8834

Volume:06, Issue:07 "July 2021"

\section{Managing the Strategic Competition}

In my opinion, the arguments between the US and China are arduous to reconcile immediately, yet Beijing and Washington should figure out a way to cooperate, regardless of how troublesome this might be.

\subsection{Need for redefining national interests}

To do so, both America and China need to amend their 'strategic mindset' and related strategies. In layman terms, both states must redefine their national interests and rules to coexist competitively. Many Chinese scholars propose that China must initiate strategic restraint. Liu Feng claims that it would not be astute for China to extend its influence across the world at a fast pace and that China needs to adopt a well-disposed strategy to amplify its regional presence. Furthermore, China and the US must define a boundary with respect to their strategic competition and esteem each other's 'core interests'. Many American scholars contend that it is essential for each state not to misrepresent each other's abilities or to misconstrue its strategic intentions. China and the United States have a big responsibility to establish a comprehensive, open and rules-based international system that assures long-term and balanced development of US-China relations. In particular, cyberspace and outer space are crucial technical fields that can worsen US-China relations. Both countries should strive to promote cooperation and find new ways to overcome other challenges, such as using artificial intelligence as a weapon.

\subsection{Increased stress over cooperation}

Also, there must not be any arbitrary contest on one another's bottom line. Both countries should cooperate in exploring mutually acceptable standards and construct an instrument to mitigate distortion. Some Chinese scholars feel that the two nations must develop 'strategic trust' and focus on 'passive cooperation'. Besides, the US-China economic relations need to be improved to prevent financial decoupling of the two nations. China must expedite steps to refine its development model and construct a matured market economy. It involves mending state-owned enterprises, financially supporting non-state enterprises and marketing market-oriented advancement in higher technological fields. Whereas, the US should assess the role of healthy, balanced globalization in aiding the US economy in achieving sustainable growth and evade depending on protectionism. Structured consultations and meetings between the two sides to moderate the negative spillover effects of their respective monetary and fiscal policies can be a game changer. Formulating cyber and tech rules, protocols, and agreements is vital for ensuring open, safe and secure connectivity. Both states, including other developed nations, should parley to establish new international standards and norms for improved management of debt risks. 


\section{International Journal of Social Science and Economic Research}

ISSN: $2455-8834$

Volume:06, Issue:07 "July 2021"

\section{Discussion}

The clashes discussed in this paper justify the world community to be anxious about being caught in the crossfire. Both states, especially the US, are eager to display their diplomatic and military power. However, it seems improbable for the US to receive full support from its allies and friends for implementing a containment strategy against China since it would be detrimental to their growth. After all, China dominates a vast range of products that are difficult to substitute for other goods. As far as a new Cold War is concerned, although undesirable, its advocates have increased after the world has witnessed a trade war and a technological war between the US and China. Yet some others are not overly pessimistic and feel that such an anomaly is not possible due to mutual economic and technological dependence between the two nations. Besides, it is imperative to understand that the fall of the United States power, in part, also stimulated a contest between the two states. The deterioration of the United States power is visible in three stages. Indeed, it all started with the 2008 global financial crisis. Later, the situation became worse in 2010-2011 when the Obama administration promoted the 'Pivot/Rebalance to Asia' strategy. In addition, China's surpassing Japan as the world's second-largest economy in 2010 fueled American concerns about a more challenging relationship with the United States. And finally, the tension towards the beginning of a new Cold War got initiated by the Trump presidency; the Trump administration's overhaul of US policy towards China injected new vitality into discussions on US-China strategic competition. Hence, it is safe to presume that USChina relations began to debilitate in the late 2000s and the US, in some sense, was responsible for bringing increased competition in the world market.

\section{Conclusion}

Although many professionals predict a further decline in US-China relations, I expect that both countries will prefer to avoid a Cold War for at least the coming few years, given the economic slowdown persisting in the world economy. I believe that interdependence between the two states makes war less probable. However, if things do escalate to trigger a Cold War, world organizations such as the United Nations can play key role in de-escalating the situation. The organization must aim to resolve the grievances of both states with harmony, such that they can bridge the gap between their ideologies and come up with a solution to solve their differences.

In any case, I reckon both countries should not strive to reform each other but jointly explore their contrasting civilizations to coexist peacefully. Both countries should respect each other's cultural traditions and historical experiences. The US must not resist China to isolate it or deny it a position of global influence. Likewise, the Chinese must understand that subverting democracies and undermining the standards, norms and institutions that are intrinsic to fair and open trade won't help in accomplishing their leadership ambitions. Other developed democracies 
International Journal of Social Science and Economic Research

ISSN: 2455-8834

Volume:06, Issue:07 "July 2021"

should also find out common approaches to managed decoupling that still allow global engagement and open trade with one another and China while encouraging reform of trade and technology governance.

\section{Acknowledgement}

I would like to express my deep and sincere gratitude to my professors at the Economics Faculty of Aryabhatta College, especially Dr. S.L. Chakravorty, for granting me the opportunity to research on the chosen topic and providing invaluable guidance throughout this research. I acknowledge them for their valuable support, cooperation and patience which helped me in successful completion of this paper.

\section{References}

1. Bannon K. Steve (2019) "We are in an Economic War with China. It is Futile to Compromise", The Washington Post, https://www.washingtonpost.com/ opinions/stevebannon-were-in-an-economic-war-with-china-its-futile-to compromise/2019/05/06/0055af36-7014-11e9-9eb40828f5389013_story. html?noredirect=on\&utm_term=.e0c48567ccb6, (21.05.2021).

2. Bijian, Zheng, (2005), “China's Peaceful Rise to Great -Power Status", Foreign Affairs, https://www.foreignaffairs.com/articles/asia/2005-09-01/chinas-peaceful-rise-greatpower-status,(21.05.2021).

3. Byun, W. See, (2016), “China's Major Powers Discourse in the Xi Jinping Era: Tragedy of Great Power Politics Revisited?”, Asian Perspective, Vol.40, N.3, pp. 493-522.

4. Chad P. Brown, (2021) "US-China Trade War Tariffs: An Up-to-Date Chart", https://www.piie.com/research/piie-charts/us-china-trade-war-tariffs-date-chart, (22.05.2021).

5. Chansoria, Monika, (2019) "China Eyes 18 Overseas Naval Bases", The Sunday Guardian, https://www.sunday-guardian.com/analysis/china-eyes-18-overseas-navalbases, (24.05.2021).

6. China Plus, (2019), “U.S. Should Focus On Its Own Race Issues, not China's Religious Policies", $\quad$ http://chinaplus.cri.cn/opinion/opedblog/23/20190720/319077.html, (24.05.2021).

7. Cohen, Saul, (2009), Geopolitics: The Geography of International Relations, Lanham, MD: Rowman and Littlefield 
International Journal of Social Science and Economic Research

ISSN: 2455-8834

Volume:06, Issue:07 "July 2021"

8. Dan, Mangan, (2020), Trump blames China for coronavirus pandemic: 'The world is paying a very big price for what they did', https://www.cnbc.com/2020/03/19/coronavirus-outbreak-trump-blames-china-for-virusagain.html, (24.05.2021).

9. Escobar, Pepe, (2019), “Chinese Scholar Offers Insight into Beijing's Strategic Mindset”, Information Clearing House, http://www.informationclearinghouse. info/50888.html, (25.05.2021).

10. Friedman, Uri, (2018), "The Trump Administration Debates A Cold War With China", The Atlantic, https://www.theatlantic.com/international/archive/2018/11/trump-xi-meetg20-new-cold-war/577045/,(26.05.2021).

11. Friedman, Uri, (2019), "The U.S. Is About to Do Something Big on Hong Kong", https://www.theatlantic.com/politics/archive/2019/09/americas-role-hong-kong/597976/, (26.05.2021).

12. Giancarlo Elia Valori, (2021), "Competition and cooperation between China and the United States and the priority”, https://moderndiplomacy.eu/2021/04/07/competition-and-cooperation-between-chinaand-the-united-states-and-the-eighth-priority/, (27.05.2021).

13. Ikenberry,John, (2008), "The Rise of China and The Future of the West", Foreign Affairs, https://www.foreignaffairs.com/articles/asia/2008-01-01/rise-china-and-futurewest, (27.05.2021).

14. Mattis, Peter and Schrader, Matt, (2019), “America Can't Beat Beijing's Tech Theft With RacialProfiling ", War on The Rocks, https://warontherocks.com/2019/07/ america-cantbeat-beijings-tech-theft-with-racial-profiling/, (28.05.2021).

15. Mackinder, H. John, "The Geographical Pivot of History”, The Geographical Journal, Vol.23, N.4, pp. 421-437.

16. Ministry of National Defense, (n.d.), “The People's Republic of China Overseas Operations", http://eng.mod.gov.cn/news/node_48721.html, (30.05.2021).

17. Ministry of Foreign Affairs The People's Republic of China, (n.d.), "China's Initiation of The Five Principles of Peaceful Co-Existence", https:/www.fmprc.gov.cn/mfa eng/ziliao_665539/3602_665543/3604_665547/t18053.shtml, (01.06.2021). 
18. Purbrick, Martin, (2017), "Maintaining A Unitary State: Counter- Terrorism Separatism and Extremism in Xinjiang and China", Journal of Asian Affairs, Vol.48, N.2, pp. 236256.

19. Roy, Denny, (2019), "Taiwan's Potential Role in the Free and Open Indo-Pacific Strategy: Convergence in the South Pacific, The National Bureau of Asian Research", NBR Special Report, N.77, https://www.nbr.org/wpcontent/uploads/ pdfs/publications/special_report_77_taiwans_potential_role_in_the_free_and_ open_indo-pacific_strategy.pdf, (04.06.2021).

20. Sorkin, R. Andrew, (2019), "What The U.S. Is About to Do Something Big on Hong KongTrump's Huawei Reversal Means For The Future of 5 G” The New York Times, https://www.nytimes.com/2019/07/01/business/ dealbook/huawei-5g-national-securitytrade.html, (04.06.2021). 